Journal of Development and Communication Studies

Vol. 4. No. 2, July 2015-June 2016 ISSN (Online \& Print): 2305-7432. bttp:/ / www.devcomsjournalmw.org.

bttp://dx.doi.org/10.4314/jdcs.v4i2.4

\title{
Agricultural Informational Flow in Informal Communication Networks of Farmers in Ghana
}

Danley Colecraft Aidoo \& Comfort Kudadjie Freeman, Department of Agricultural Extension, College of Basic and Applied Sciences, University of Ghana, Accra, Ghana.

\begin{abstract}
Despite the rapid growth in the use of modern communication media to improve access to agricultural information, local information networks remain an important means of communication among rural folk. This study examined informal communication networks of rural farmers in the Ahafo Ano south district of Ghana to determine how they can be harnessed to improve the provision of agricultural information. The objectives were two-fold, to: (i) identify local information networks and characteristics of the key communicators and (ii) determine how the structural properties of the networks affect the flow of agricultural information. Snowball sampling was used to select respondents from three purposively-selected communities in the district. Sociograms were used to reveal the ties between network actors. Key communicators of agricultural information were found to be significantly older and had higher farm output than the rest of the population and tended to occupy leadership positions in their community. Thus, extension service providers should target such key communicators when introducing new information and technology as they can serve as essential channels of information to other farmers in the community. It was also observed that network density values were generally low indicating that the networks are open to diverse sources of information. Low degree centrality measures indicated frequent sharing of information among several central actors rather than through one central person. Agricultural extension service providers should identify such farmers who can serve as intermediaries between actors to belp disseminate information in rural communities.
\end{abstract}

Keywords: key communicators, farmers, rural communities, social networks, extension agents

\section{Introduction}

Information is fundamental to our way of life and agriculture is no exception. Farmers need access to reliable information and knowledge along the value chain to improve their productivity. Information sources and channels available to farmers include libraries, internet, extension agents, research organizations, radio, television, community based organizations, neighbours, family, fellow farmers (farmer to farmer communication), cooperative groups and societies, traders, etc. (Ngathou, Bukenya, \& Chembezi, 2006; Daudu, Chado, \& Igbashal, 2009; and Mwalukasa, 2013). In view of the rapid growth and expansion of communication technologies there has been a lot of research in the area of communication and agricultural development. However, the focal point of researchers have been geared towards modern communication media, and how these can contribute to improving access to agricultural information. On the other hand, interpersonal communication is invaluable to communication among the rural folk who incidentally are at the core of agriculture. 
Several studies highlight the potential of interpersonal communication. For instance, Licht \& Martin (2007), Lwoga, Stilwell, Ogbama (2010), Ngulube (2011), and Okwu and Daudu (2011) realized that friends, relatives and neighbours are regularly available and accessible to the farmers to gain the agriculture information they need. According to Leeuwis (2013), to a large extent the dynamics of diffusion methods rely on horizontal communication among farmers. Farmers scrutinize and have their perception of other farmers' skills, practices and performance, and they discover more by discussing their own experiences with friends and neighbors. Opinion leaders, who are also local farmers, are good sources of new information and advice. They usually enjoy considerable authority on the way other locals think and behave (Rogers, 2003). The argument that rural farmers prefer farmer-to-farmer communication is supported by several studies that indicate that even in communities where social organisation and infrastructure exist, farmers favor their colleague farmers as their prime information source (Demiryurek, 2008). In their study on the effectiveness of the farmer-to-farmer extension approach in Uganda, Ssemakula and Mutimba (2011) also found that there was a high level of communication between farmers compared to what existed between the farmers and any other individuals or extension service providers.

In Ghana, the Ministry of Food and Agriculture (MOFA) which is the major source of information to farmers, is faced with several constraints. One of such constraints relevant to this study is the low extension - farmer ratio. In the Ahafo Ano South district where this study was conducted, the extension agent - farmer ratio is 1:2,171 (Ghana Statistical Service, 2014). Even though this ratio is better than the national figure which stands at 1:3000, this situation negatively affects the availability of agricultural information to farmers in the district and the country at large (Ghana Statistical Service, 2014). A study conducted in the Atwima Mponua and Amansie West districts in the Ashanti region of Ghana found that $83.8 \%$ of farmers had not met an extension agent in the year preceding the study. The farmers relied heavily on their network of family members and friends for information on cocoa and only 13\% regarded the extension system as a reliable information source (Baah, 2008).

The result is a lack of an effective farmers' information support system to support the farming activities in the country and farmers tend to rely on their own informal information sources. Even in instances where there has been some level of agricultural information dissemination through the mass communication media, farmers have very little choice with respect to the kind of information available to them. Siraj (2012) attests to the fact that rural populations are not only resource poor but also information poor. In addition, Ngwenyama, Andoh-Baidoo, Bollou, and Morawecynski (2006:4) observed that "in Africa, three quarters of the population is illiterate and lives in rural areas that lack basic facilities such as electricity and to expect effective utilisation of communication technologies like the Internet in all areas, by all people, would be unreasonable".

This view is also supported by Ghatak (2007) who identified constraints such as differing literacy, poor technical skills and lack of practical digital content to the use of communication technologies. The constraints associated with the use of ICTs especially in rural areas as well as their limited access to agricultural extension agents make it necessary to consider the potential of informal information networks for improving the provision of agricultural information.

\section{Objective of the Study}


The main objective of this study was to examine the informal communication networks of rural farmers in the Ahafo Ano south District of Ghana in order to determine how they can be harnessed for the provision and flow of agricultural information.

\section{Research Questions}

The following research questions were posed to achieve the above objective:

RQ 1: What are the characteristics of major providers of agricultural information in the local information networks identified?

RQ 2: How do the structural properties of the existing networks affect the flow of agricultural information?

\section{Theoretical Framework}

The social network theory forms the basis of the theoretical framework from which the study was derived. Serrat (2010) describes social networks as nodes of individuals, groups, organizations, and related systems that tie in one or more types of interdependencies such as shared values, visions, and ideas; social contacts, kinship, conflict, financial exchanges, trade, joint membership in organizations, and group participation in events, among numerous other aspects of human relationships. The theory views social relations basically in terms of nodes and ties. The nodes correspond to individual actors while the ties stand for the relationships or linkages between the actors. The focal point of network analysis is to identify the relationships between people. This method focuses on informal relationships, indicating how existing informal interactions ease or hinder the transfer of information and knowledge or more concrete items such as commodities and currency. By expressing these interactions in the form of sociograms (a graph that depicts the social relations in a group), network analysis helps to reveal the unofficial communication patterns that exist in a community, group or organization. Social network analysis has been applied in a wide range of academic disciplines such as anthropology, business studies, communication studies, information science, organizational studies, development studies and literature studies (De Nooy, 2003). This study however dwells on the flow of agricultural information through informal interactions between members of social networks.

\section{Method}

The study was conducted in Ghana, West Africa, in the Ahafo Ano South district located in the Ashanti Region. The District is predominantly rural (90\%) with over 160 organised settlements and has a population of 121,659 (Ghana Statistical Service, 2014). The major crops grown by farmers in the area are cash crops, such as cocoa, citrus, oil palm and food crops like rice, plantain, cassava, cocoyam, maize and vegetables (tomatoes and okra). Both qualitative and quantitative methods were employed in the study. The study adopted the snowball method of sampling for network analysis as proposed by Hanneman and Riddle (2005). The snowball method begins with a central actor or set of actors. Each of these actors is asked to name some or all of their ties to other actors. Then, all the actors identified (who were not part of the initial listing) are tracked down and asked to name their ties. The process continues until no new actors are identified. Data was collected primarily by means 
of administered questionnaires. Respondents were selected from three communities in the district namely; Kunsu, Afreseni, and Dunyankwanta. These separate communities were similar in terms of crops grown, existing farmer groups, and access to land. Only one farmer (an individual who owned or rented land and had an established farm) was selected from each household to be interviewed. Additional questionnaires were also administered to actors identified as key communicators in order to determine their sources of information, information sharing habits, and their positions or status in the community.

Farmer responses were coded in terms of dual variables (distinguishing between the presence or absence of ties), to allow entry into a name-based adjacency matrix (Hanneman and Riddle, 2005). The coded responses were entered into Pajek (Batagelj and Mrvar, 2007) to create socio-grams and analysed with the aid of the software Ucinet 6 for Windows (Borgatti, Everett and Freeman, 2002). The sociograms were created according to the core-periphery model (Cattani and Ferriani, 2008). The Core-periphery model sorted actors in each network into two categories, one category for highly sought farmers and the other for farmers who are less consulted. The networks were also analysed in terms of network descriptors such as network size, network degree centrality (number of mentions held by various farmers), and betweeness centrality (level at which some farmers are placed centrally among other farmers). Degree Centralization measures are done by expressing the extent of inequality or variance in the network as a percentage of that of a perfect network of the same size. Betweeness Centralization measures determine influential actors in terms of their control over the flow of information by virtue of their position as intermediaries connecting many pairs of other actors in the network.

\section{Findings}

\section{Local information networks identified in Abafo Ano South District}

One local information network was observed in each of the three communities studied. These networks had varying sizes yet shared common characteristics. The networks portrayed the social relations existing in each community, revealing unofficial communication patterns that exist in the community. All the sociograms displayed a core-periphery structure (see Figure 1, 2 and 3). Core farmers were consulted by other core and periphery farmers more often than the other farmers, leading to a high number of information ties originating from within the small group (core farmers). The information centred on fertilizer application, weed and pest control, choice of planting materials, and harvesting and marketing of cocoa and rice. The mode of communication was oral during home and farm visits, informal conversations and group meetings. The information network in Kunsu had a network size of thirty-two and the Afreseni information network consisted of fiftyeight members while the Dunyankwanta network revealed seventy-two members. 


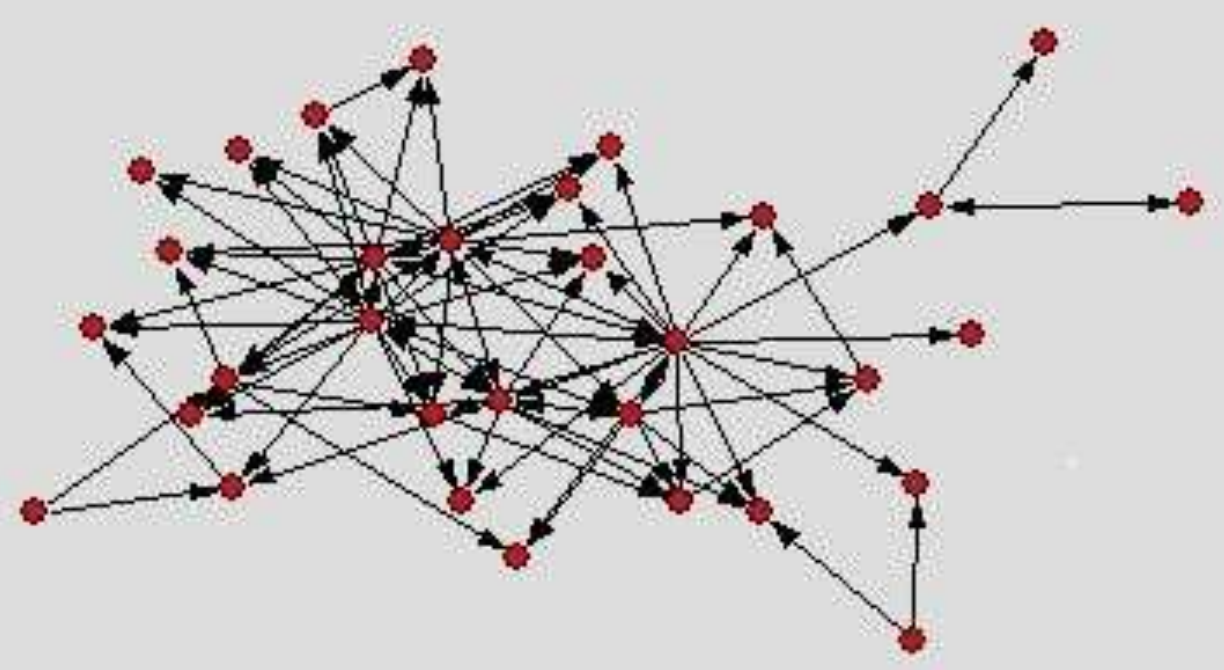

Figure 1. Socio-grams for agricultural information networks in Kunsu. Nodes represent individual farmers and direction of arrows denotes direction of information flow. Doubleended arrows symbolize reciprocal ties.

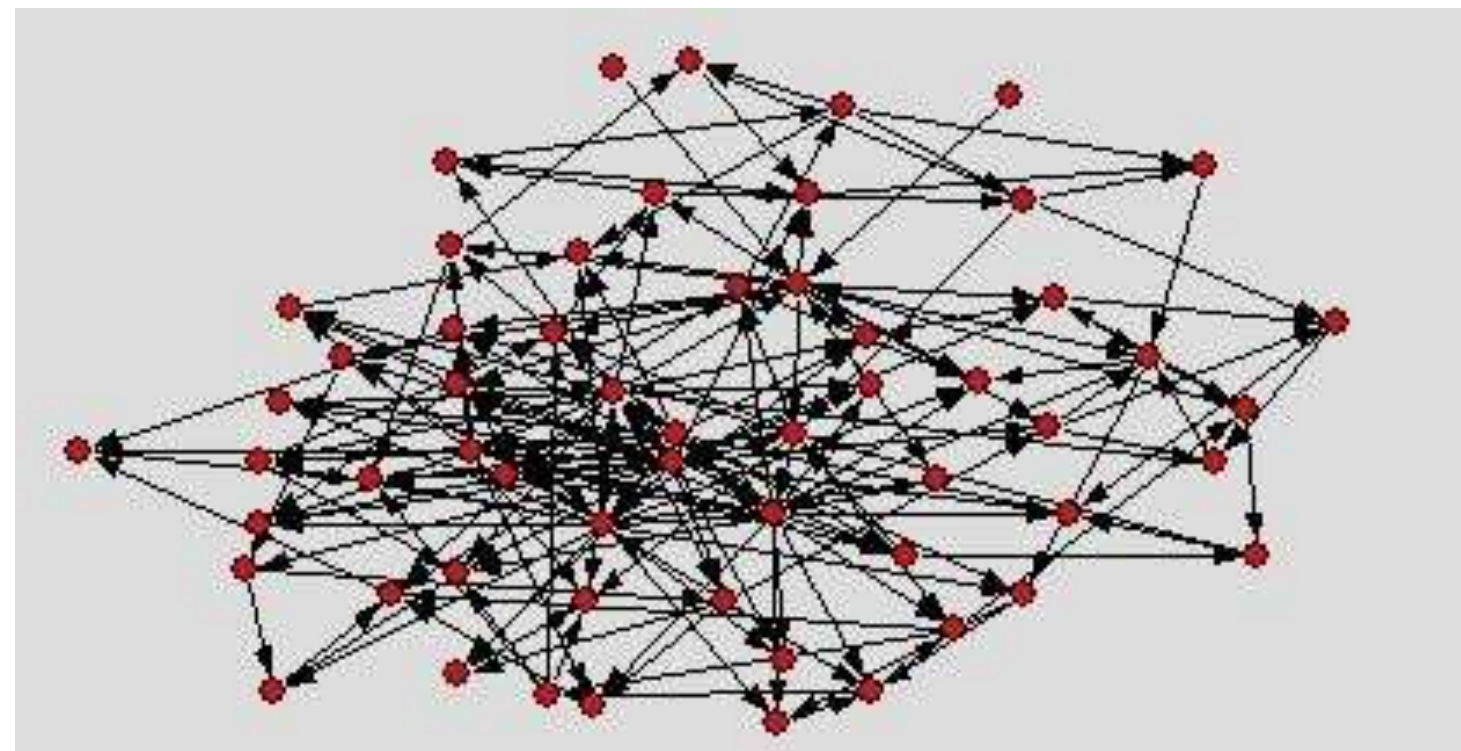

Figure 2. Socio-grams for agricultural information networks in Afreseni. Nodes represent individual farmers and direction of arrows denotes direction of information flow. Doubleended arrows symbolize reciprocal ties. 


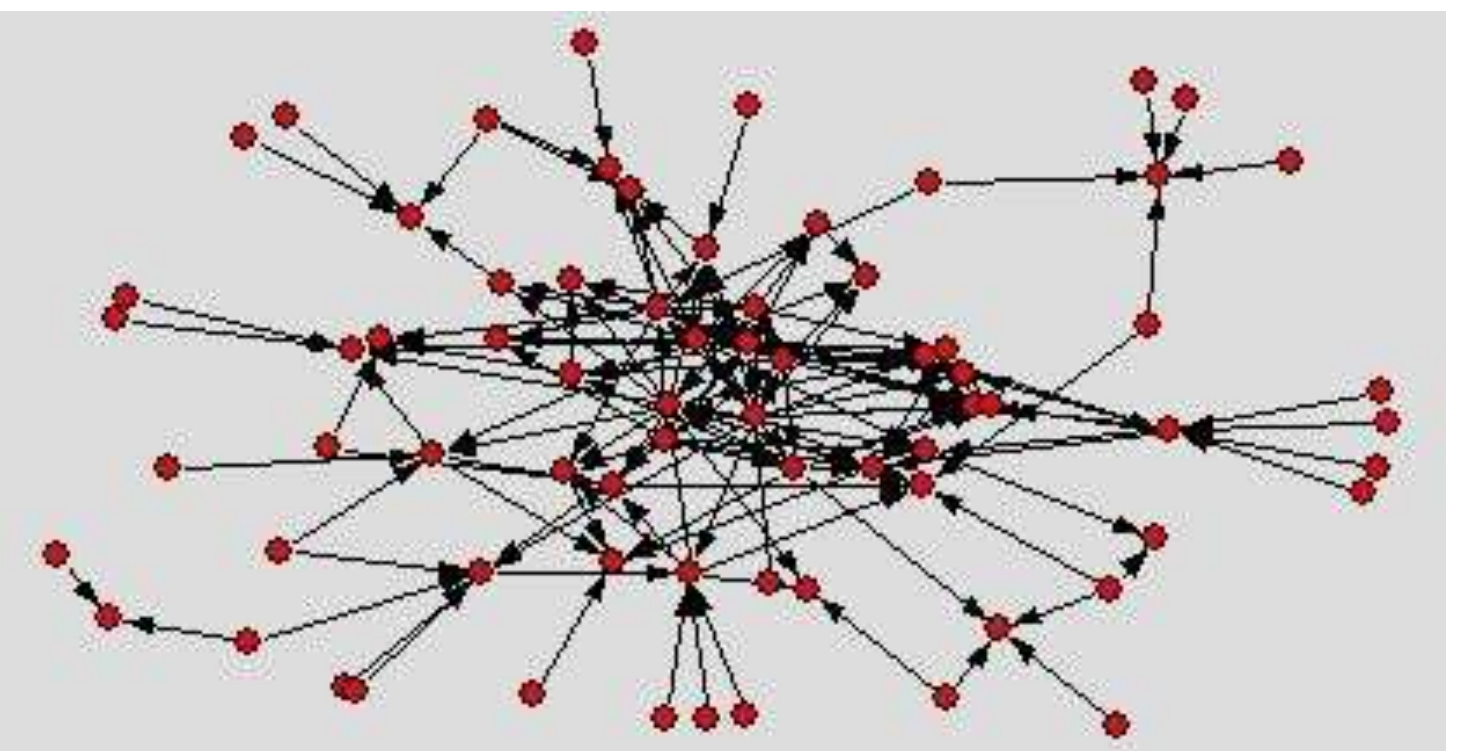

Figure 3. Socio-grams for agricultural information networks in Dunyankwanta. Nodes represent individual farmers and direction of arrows denotes direction of information flow. Double-ended arrows symbolize reciprocal ties.

\section{Characteristics of the major providers of agricultural information}

A total of 23 major providers of information (referred to as key communicators in this study) were identified in the three networks: six in Kunsu, eight in Afreseni and nine in Dunyankwanta. All key communicators in Kunsu occupied leadership positions in their communities such as chairperson or financial secretary of the farmer groups to which they belonged. Four and seven key communicators in Afreseni and Dunyankwanta respectively were also found to be leaders in their communities. Characteristics of key communicators such as age, farm output per acreage and training were studied in comparison to the characteristics of the population ( Table 1). Key communicators in all three networks were found to be significantly older than the rest of the population when the means of both groups were compared using a one-sample $t$-test. The key comrmunicators also had significantly higher output per acreage. Thus key communicators who were consulted most turned out to be comparatively older and more successful in farming. All the 23 key communicators have benefitted from training programs from MoFA and non-governmental organizations in areas like choice of good planting material (cocoa), weed and disease control, fertilizer application (cocoa), proper record keeping, and proper use of chemicals (fertilizers, pesticides, herbicides, etc.) in cocoa and rice production.

Table 1: One-sample t-test for Average Age and Output of Key Communicators in Dunyankwanta, Kunsu and Afreseni

\begin{tabular}{|c|c|c|c|c|c|c|c|}
\hline \multirow[t]{2}{*}{ Community } & \multirow[t]{2}{*}{ Characteristics } & \multirow[t]{2}{*}{$\overline{\mathrm{T}}$} & \multirow[t]{2}{*}{ Df } & \multirow[t]{2}{*}{$\begin{array}{l}\text { Sig. } \\
\text { Tailed) }\end{array}$} & \multirow[t]{2}{*}{$\begin{array}{l}\text { Mean } \\
\text { Difference }\end{array}$} & \multicolumn{2}{|c|}{$\begin{array}{l}95 \% \text { Confidence } \\
\text { Interval Of The } \\
\text { Difference }\end{array}$} \\
\hline & & & & & & Lower & Upper \\
\hline Dunyankwanta & Average Age & \multicolumn{6}{|c|}{ Test Value $=40.2$} \\
\hline
\end{tabular}




\begin{tabular}{|c|c|c|c|c|c|c|c|}
\hline & & $3.242^{*}$ & 8 & .012 & 12.689 & 3.66 & 21.71 \\
\hline & \multirow[b]{2}{*}{ Average Output } & \multicolumn{6}{|c|}{ Test Value $=5.10$} \\
\hline & & $6.402^{*}$ & 8 & .000 & 1.45556 & .9312 & 1.9799 \\
\hline \multirow[t]{4}{*}{ Kunsu } & \multirow[t]{2}{*}{ Average Age } & \multicolumn{6}{|c|}{ Test Value $=38.8$} \\
\hline & & $2.693^{*}$ & 5 & .043 & 8.867 & .40 & 17.33 \\
\hline & \multirow[t]{2}{*}{ Average Output } & \multicolumn{6}{|c|}{ Test Value $=4.52$} \\
\hline & & $9.490^{*}$ & 5 & .000 & 2.647 & 1.9298 & 3.3636 \\
\hline \multirow[t]{4}{*}{ Afreseni } & \multirow[t]{2}{*}{ Average Age } & \multicolumn{6}{|c|}{ Test Value $=36.6$} \\
\hline & & $4.073^{*}$ & 7 & .005 & 13.275 & 5.57 & 20.98 \\
\hline & \multirow[t]{2}{*}{ Average Output } & \multicolumn{6}{|c|}{ Test Value $=4.71$} \\
\hline & & 15.298* & 7 & .000 & 2.47750 & 2.0946 & 2.8604 \\
\hline
\end{tabular}

$* \mathrm{p}<.05$

Structural Properties of the existing networks and the flow of Agricultural information.

The structural properties of the networks studied in the three communities are; network density, degree centralization, and betweenness centralization. The density of ties between core and periphery groups was used to indicate the rate at which information spread across and within the groups. Table 2 shows that in all the networks farmers in the core group sought advice from other core acquaintances more often than from farmers in the periphery, resulting in a high level of communication within the smaller core group. Generally, the comparatively small, dense cluster of farmers (core) was consulted by both members of the core and periphery groups for agricultural information. On the whole, the core group was prominent in the transmission of agricultural information to the larger population in all three communities.

Table 2: Density of ties between core and periphery groups in the Kunsu, Afreseni and Dunyankwanta agricultural information networks

\begin{tabular}{|l|l|l|l|}
\hline Network & & Core & Periphery \\
\hline \multirow{3}{*}{ Kunsu } & Core & 0.733 & 0.359 \\
\cline { 2 - 4 } & Periphery & 0.013 & 0.023 \\
\hline \multirow{2}{*}{ Afreseni } & Core & 0.411 & 0.237 \\
\cline { 2 - 4 } & Periphery & 0.023 & 0.032 \\
\hline \multirow{2}{*}{ Dunyankwanta } & Core & 0.444 & 0.162 \\
\cline { 2 - 4 } & Periphery & 0.009 & 0.024 \\
\hline \multicolumn{2}{|l|}{} \\
\hline
\end{tabular}

The three networks displayed considerable variability in terms of density, degree centralization, and betweenness centralization (see Table 3). The density across the networks decreased as the size of the network increased. A higher variability was observed across the actors in terms of outdegree than indegree (standard deviations). This indicates the heterogeneous features of the networks in terms of structural positions occupied by central actors. The central tendency values (mean and standard deviation) for betweenness centrality also displayed a relatively high variation in actor betweenness (comparing the standard deviations to the means). This is logical, considering the fact 
that not all actors in the various networks were identified as influential to agricultural information provision.

Table 3: Mean and (SD) of density, degree, and betweenness parameters averaged over the networks

\begin{tabular}{lllll}
\hline Community & Density & Degree & Betweeness \\
\cline { 3 - 5 } & & InDegree & OutDegree & \\
\hline Kunsu & 0.096 & $2.969(5.199)$ & $2.969(1.262)$ & $9.842(18.008)$ \\
Afreseni & 0.062 & $3.552(5.018)$ & $3.552(1.262)$ & $63.021(87.732)$ \\
Dunyankwanta & 0.043 & $3.083(4.499)$ & $3.083(1.898)$ & $39.325(94.349)$ \\
\hline
\end{tabular}

\section{Discussion}

The study found that major providers of agricultural information or key communicators were significantly older, had higher farm output than the rest of the population and tended to occupy leadership positions in their community. Borgatti and Everett (1999) observed that in a coreperiphery network there exists a group of agents that is densely connected internally, while all remaining network members are sparingly connected among themselves. Barsky (1999) also proposed that core-periphery models in information networks develop from a persistent choice of exact actors who possess exclusive characteristics that enhance their entry into the core membership group. Mittal and Mehar (2013) also indicate that older farmers are more likely to be consulted by younger farmers for agricultural information. Other authors also posit that farmers who have higher yields and are seen as successful by other farmers tend to provide information to other farmers and are seen as role models (Borgatti, 2005; Goswami \& Basu, 2010). Rogers (2003) also noted that farmers in leadership positions in their local communities are indispensable with respect to providing agricultural information to farmers and influencing adoption of new agricultural technologies.

With regard to our second research question our findings showed that network densities decreased with increasing size. Noor, Mrvar, and Batagelj (2005) explain that density is inversely related to the size of a network; the larger the social network, the lower the density because the number of possible ties increases rapidly with the number of actors, whereas the number of ties which each person can maintain is limited. Leonard (2008) further states that the closer the density value is to zero, the slower the flow of information in the network becomes. Smaller information networks are therefore preferable when seeking to strengthen adoption of agricultural technologies as compared to larger networks where the strength of relationship between actors is reduced.

The networks did not show any considerable differences with respect to the whole network centrality measures. The low degree centrality measures indicate that despite the presence of a significant quantity of centralization within the networks, the influence of the various actors differ and there is a considerable disparity in the amount of power wielded by influential actors in the networks. This is explained by the fact that the key communicators who possess high amounts of ties are comparatively few as compared to the other actors. Marks et al (2013) explain that low network degree centralization measures as seen in the three networks indicate that actors in the network share frequent and valuable information with one another through relationships with 
several central individual actors rather than through one centralized person or position, thus reducing the danger of information flow being dependent on just one central actor.

In the three networks, the network betweenness centralization were relatively low. As Hopkins (2011) explains, low betweenness scores indicates that the actors are situated between few pairs of other actors. The low mean betweenness scores of the networks, the large number of actors with a betweenness measure of zero, and the extremely low network betweenness centralization index across all three networks indicate that there are few information brokers within the networks. However, it must be pointed out that the sociometric method fails to account for knowledge transmitted by means of circumstantial learning and unsolicited information, leading to low betweenness centralization measures.

\section{Conclusions and Recommendations}

The findings of the study indicated the presence of a network for transmission of agricultural information in each of the three rural communities. Key communicators turned out to be farmers who were older, successful in farming and had access to training and information from external sources. Thus the social status of individuals in a network is to an extent indicative of their performance in terms of agricultural information provision. It is therefore suggested that extension agents should identify and contact such key communicators who are highly sought after or consulted by their peers when introducing or transferring technologies and specialized information in these communities.

Significant but weak network ties found among members of the networks also suggest that other actors also facilitated the flow of information through the network. Network properties indicate that people who seem to have little influence within a social structure may have close links with influential actors within or outside the structure. Due to their positions in the social network the presence of these 'informal leaders' is important for effective provision of agricultural information. This implies that in addition to central actors who are responsible for the generation and flow of agricultural information, there are other network members who are important in terms of connecting individuals. It is recommended that in disseminating information in such rural communities, extension service providers should identify not just actors who have numerous ties with many others (central actors), but should also make use of farmers who can serve as intermediaries by virtue of their links between actors.

This study focused on measures of social network analysis observed at a particular point of time. Subsequent research may possibly investigate how these measures and their influence on information availability vary over time. In addition, since the study used a representative model of just one district in the country (with mainly cocoa and rice farmers), further studies could be focused on understanding the informal information networks that exist in larger geographical areas and with more crop diversity.

\section{References}

Adjaye, J. K., \& Aborampah, O. (2004).

Intergenerational cultural transmission among the Akan of Ghana. Journal of Intergenerational Relationships: Programs, policy, and research, 2(3/4), 23-38.

Baah, F. (2008). 
Cocoa Farmer Characteristics and Access to Research Based Information in Two Districts of Ashanti, Ghana. Journal of Science \& Technology (Ghana), 28 (3), 10-18. Doi: http:www.ajol.info/index.php/just/article/viewFile/33095/37291

Barsky, N. P. (1999).

A core/periphery structure in a corporate budgeting process. Connections, 22,1-29.

Batagelj, V. A., \& Mrvar, A. (2003).

Pajek: Analysis and visualization of large networks. In M. Jünger \& P. Mutzel (Eds.), Graph drawing software (pp. 77-103). Berlin: Springer.

Borgatti, S. P., \& Everett, M.G. (1999). Models of core/periphery structures. Social Networks, 21, 375-395.

Borgatti, S. P., Everett, M. G., \& Freeman, L. C. (2002)

Ucinet for Windows, Software for Social Network. Analysis, Harvard: Analytic Technologies, 2002 (UCINET 2002).

Borgatti, S. P. (2005).

Centrality and Network Flow. Social Networks 27, 55-71.

Cattani, G., \& Ferriani, S. (2008).

A Core/Periphery Perspective on Individual Creative Performance. Organization Science 19(6), pp. 824-844, (C) 2008 INFORMS

Daudu, S., Chado, S.S., \& Igbashal, A.A. (2009).

Agriculture information sources utilized by farmers in Benue state, Nigeria. Patsunk J, 5, 3948.

Demiryurek, K., Erdem, H., Ceyhan, V., Atasever, S. \& Uysal, O. (2008).

"Agricultural information systems and communication networks: the case of dairy farmers in Samsun province of Turkey". Information Research, 13(2), paper 343. Doi: http://InformationR.net/ir/13-2/paper343.html

De Nooy, W. (2003).

Fields and networks: Correspondence analysis and social network analysis in the framework of Field Theory. Poetics, 31, 305-327.

Feder, G., \& Slade, R. (1985).

The role of public policy in the diffusion of improved agricultural technology; American Journal of Agricultural Economics, 67(2), 423-428.

Ghana Statistical Service (2014).

2010 Population and Housing Census. District Analytical Report. Ahafo Ano South District. Retrieved from www.statsghana.gov.gh/pop stats.html

Ghatak, S. (2007). Brief note on ICTs. Retrieved from http://topics.developmentgateway.org/poverty/rc/filedownload.do,itemId $1 / 41098665$

Goswami, R., \& Basu, D. (2010).

Does Information Network Affect Technology Diffusion? A Study on the Spread of Banana and Guava Cultivation among Farmers of Nadia District, West Bengal, India. Research Journal of Agriculture and Biological Science, 6(6), 701-707. Retrieved from htttp://www.insipub.com/rjabs/2010/701-707.pdf

Gueye, E. F. (2009).

The Role of Networks in Information Dissemination to Family Poultry Farmers. World's Poultry Science Journal, 65, 115-124. do:10.1017/S0043933909000099

Hanneman, R.A. \& Riddle, M. (2005). Introduction to Social Network Methods. Riverside CA, University of California. 
Leonard, J. N. (2008).

Role of Social Network Structure in the Governance of Great Lakes Transboundary Fish Stocks. Michigan State University. ProQuest, UMI Dissertation Publishing, Michigan, USA.

Licht, M., \& Martin, R.A. (2007).

Communication channel preferences of corn and soybean producers. Journal of Extension, 45,(6). Retrieved from http://www.joe.org/joe/2007december/rb2p.shtml.

Lwoga, E.T., Stilwell, C., \& Ngulube, N. (2011).

Access and use of agricultural information and knowledge in Tanzania. Journal of Agricultural Knowledge and Information, 60, 383-39.

Marks, J., Barnett, L. M., Foulkes, C., Hawe, P., \& Allender, S. (2013).

Using Social Network Analysis to Identify Key Child Care Center Staff for Obesity Prevention Interventions: A Pilot Study. Journal of obesity, doi: 10.1155/2013/919287

Mittal, S., \& Mehar, M. (2013).

Agricultural Information Networks, Information Needs, and Risk Management Strategies: a survey of farmers in Indo-Gangetic Plains of India. Socioeconomics Working Paper 10. Mexico, D.F.: CIMMYT

Mundy, P. \& Compton, J. (1995).

Indigenous Communication and Indigenous Knowledge. In Warren, M., Slikkerveer, L. and Brokensha, D. (Eds.), The Cultural Dimension of Development: Indigenous Knowledge Systems (pp. 112-123) . Intermediate Technology, London.

Mwalukasa, N. (2013).

Agricultural Information Sources used for Climate Change Adaptation in Tanzania. Library Review. Vol. 62, (4/5), 266-292.

Ngathou, N.I., Bukenya, J.O., \& Chembezi, M.D. (2006).

Managing Agricultural Risk: Examining Information Sources Preferred by Limited Resource Farmers. Journal of Extension, 44(6), doi: http://www.joe.org/joe/2006december/a2.php

Noor, W. D., Mrvar, A., \& Betagelj, V. (2005). Exploratory Network Analysis with Pajek. Cambridge University Press. Cambridge: New York.

Ogboma, M.U. (2010). Access to agriculture information among fish farmers in Niger delta region of Nigeria. Journal of Library Philosophy and Practice. Retrieved from http://www.faqs.org/periodicals/201009/2166597671.htm

Okwu, O.J. \& Daudu, S. (2011).

Extension communication channels' usage and preference by farmers in Benue state Nigeria. Journal of Agricultural Extension and Rural Development, 3, 88-94.

Rogers, E. M. (2003).

Diffusion of Innovations (4th eds.). Simon and Schuster: The Free Press.

Serrat, O. (2010).

Social network analysis. Washington, DC: Asian Development Bank.

Siraj, M. (2012).

A model for ICT based services for agricultural extension in Pakistan. CABI South Asia. Retrieved from www.r4d.dfid.gov.ukPDF?OUTPUTS?MISC info

Ssemakula, E., \& Mutimba, J. K. (2011).

Effectiveness of the farmer-to-farmer extension model in increasing technology uptake in Masaka and Tororo Districts of Uganda. South African Journal of Agricultural Extension, 39(2), $30-46$. 